\title{
Investigating the relationship between the prey composition of Barn Owls (Tyto alba) and the habitat structure of their hunting range in the Marcal Basin (Hungary), based on pellet analysis
}

\author{
Dávid Szép ${ }^{1 *}$, Ákos KLeIN ${ }^{2} \&$ Jenő J. Purger ${ }^{1}$ \\ Received: March 11, 2019 - Revised: April 29, 2019 -Accepted: April 30, 2019
}

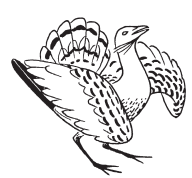

Szép, D., Klein, Á. \& Purger, J. J. 2019. Investigating the relationship between the prey composition of Barn Owls (Tyto alba) and the habitat structure of their hunting range in the Marcal Basin (Hungary), based on pellet analysis. - Ornis Hungarica 27(1): 32-43. DOI: 10.2478/ orhu-2019-0002

\begin{abstract}
Little was known about the small mammal fauna of the Marcal Basin to date, therefore we collected 1,144 Barn Owl pellets from 15 locations in 2017. After the analysis of the pellets, remnants of 3,063 prey items were identified, of which $97.5 \%$ were small mammals, belonging to 21 species, while the remaining $2.5 \%$ were birds, frogs and insects. Mammal prey items consisted of Cricetidae $41 \%$, Muridae $31 \%$ and Soricidae $28 \%$, and in some samples, we found the remnants of European Mole (Talpa europaea), Kuhl's Pipistrelle (Pipistrellus kuhlii), Hazel Dormouse (Muscardinus avellanarius) and Least Weasel (Mustela nivalis). Small mammal species were classified into four functional groups based on their preferences for urban, open, forest or wetland habitats. We investigated whether their relative abundances match with the proportions of the four habitat types in the assumed Barn Owl hunting ranges (cca. $2 \mathrm{~km}$ radius circle) in five sample sites. The relative abundance of small mammal species preferring urban habitats showed concordance with the proportion of the appropriate habitat types in the hunting area in two samples, while such concordance was proved for species favouring open, forest and wetland habitats just in one out of five samples. Small mammal functional groups represented in the prey composition do not directly correspond to the proportion of their typical habitats. We conclude that the abundance of various prey types is not suitable for characterising the landscape within the Barn Owl's hunting range.
\end{abstract}

Keywords: pellets, small mammals, habitat preference, landscape structure

Összefoglalás A Marcal-medence kisemlős faunájáról ezidáig keveset tudtunk, ezért 2017-ben 15 településröl 1144 gyöngybagolyköpetet gyüjtöttünk. Szétbontásuk és elemzésük során 3063 zsákmány maradványa került elö, melynek 97,5\%-át 21 kisemlös faj egyedei tették ki, míg a fennmaradó 2,5\% madár, béka, illetve rovar volt. Az emlőszsákmány 41\%-a hörcsögfélékböl (Cricetidae), 31\%-a egérfélékből (Muridae) és 28\%-a cickányfélékböl (Soricidae) állt, de előkerültek közönséges vakond (Talpa europaea), fehérszélű törpedenevér (Pipistrellus kuhlii), mogyorós pele (Muscardinus avellanarius) és eurázsiai menyét (Mustela nivalis) maradványok is. A baglyok zsákmányából kimutatott kisemlősöket funkcionális csoportokba soroltuk, az alapján, hogy urbán, nyílt, erdős vagy vizes élőhelyeket preferálnak. Azt vizsgáltuk, hogy részesedésük mutat-e egyezést a felsorolt négy élöhelytípus részesedésével a baglyok feltételezett $2 \mathrm{~km}$ sugarú körön belüli vadászterületein, öt mintaterületen. $\mathrm{Az}$ urbán élőhelyeket preferáló fajok részesedése két mintában, míg a nyílt, erdei és vizes élőhelyeket preferáló fajok részesedése csak egy-egy mintában mutatott hasonlóságot a megfelelő élőhelytípus részesedésével a feltételezett vadászterületen belül. A zsákmányból kimutatott kisemlösök funkcionális csoportjainak részesedése nem egyezett meg a megfelelő élőhelyeik arányával. Megállapíthatjuk, hogy ezzel a módszerrel a kisemlős zsákmány alapján nem tudtunk következtetni a vadászterület élöhelyeinek mintázatára. 
${ }^{1}$ Department of Ecology, Institute of Biology, University of Pécs, 7624 Pécs, Ifjúság útja 6., Hungary
${ }^{2}$ The Barn Owl Foundation, 8744 Orosztony, Temesvári utca 8., Hungary
* corresponding author: szeep.david@gmail.com

\section{Introduction}

Small mammals are the main preys of the Barn Owl (Tyto alba) (Mikkola 1983). Many rare or elusive species occur among the prey, just as well ones that can be hardly caught by trapping (Torre et al. 2004, 2015). On the basis of the prey composition found in the pellets, valuable data can be obtained about the species in the owl's hunting area, therefore this indirect method is often used for surveying the fauna (e.g. Schmidt 1976, Taylor 1994, Yom-Tov \& Wool 1997). The composition of small mammal communities can be better estimated based on these data in comparison with standard direct sampling methods, e.g. trapping (Heisler et al. 2016). However, such studies should not ignore the seasonal dynamics of small mammals, the population outbreaks, and the fact that Barn Owls can show prey preference during hunting (Tores et al. 2005, Askew et al. 2007, Meek et al. 2012). The structure of small mammal communities is also influenced by the landscape (Torre et al. 2015), therefore, the results of pellet analysis can be used for the description of the landscape (Heisler et al. 2016), moreover the changes in land use can be detected by using data of long-term owl pellet analysis (Cooke et al. 1996, de la Peña et al. 2003, Rodríguez \& Peris 2007).

Little was known about the small mammal fauna of the Marcal Basin to date (Bihari et al. 2007). A few previous studies of Barn Owl pellet analysis were performed (e.g. Schmidt 1976, 1979, Lázár 1983, Varga 1986, 1991, Purger \& Reider 1998, Szép \& Purger 2013). In the southern part of the Marcal Basin two surveys were conducted at the same place, but in different times (Lázár 1983, Szép \& Purger 2013), and upon comparison of the results of the studies it was suggested that differences in the relative abundance of species found in Barn Owl pellets may indicate changes in land use (Szép \& Purger 2013). This example pointed out that results from previous sporadic surveys can provide a good basis for comparisons if more pellets can be collected in the same sites. However, if pellet samples are collected at the same time, from several areas with similar landscape features, we assume that the differences in the small mammal composition refer to the habitat conditions of the owls' hunting areas.

The aims of this study were: 1) to widen our knowledge on the small mammal fauna of the Marcal Basin based on Barn Owl pellet analysis, 2) to find connection between the proportions of the functional groups of small mammals in the diet and the proportion of their favoured habitats in the owls' hunting areas.

\section{Materials and methods}

The Marcal Basin is mostly flat, lowland area $\left(1,583 \mathrm{~km}^{2}\right)$ situated in the north-western part of Hungary (Dövényi et al. 2010). Its greater part is agricultural landscape, while the small patches of natural vegetation consist of oak-hornbeam forests, gallery forests as well as 
tall-sedge beds along the Marcal and other watercourses (Mesterházy 2008). Approximately $18 \%$ of the area is covered by forests, and out of this $70 \%$ comprise plantations of black pine (Pinus nigra) and black locust (Robinia pseudoacacia) (Mesterházy 2008). The catchment area of River Marcal is in the basin, with a lot of watercourses (Dövényi et al. 2010). The climate is temperate continental, with an average annual temperature of $10.0^{\circ} \mathrm{C}$, and annual precipitation varying between 580 and $700 \mathrm{~mm}$ (Dövényi et al. 2010).

Barn Owl pellets were collected in the Marcal Basin in 2017 (Figure 1). The dates indicate only the time of collection (Table 1a, b). Small mammals detected in the pellets were identified on the basis of skeletal parameters (Schmidt 1967, Tvrtković 1979, Tvrtković et al. 1980, Ujhelyi 1989, Kryštufek \& Janžekovič 1999, März 2011). Their quantity was calculated by counting the number of skulls and their corresponding jaws. The identification of amphibians was performed based on Paunović's identification key (1990), and that of the birds on Kessler's identification key (2015).

Small mammals detected in the owl pellets were classified into four functional groups according to their preferences for urban, open, forest or wetland habitats (Table 1a, b). In order to study the connection between the proportions (in Barn Owl diet) of the functional groups of small mammals of habitats in the hunting range, we used the 5 largest samples (Table 1a, b). To our knowledge, Barn Owls hunt at a distance of about 1-3 km from its nesting or roosting place, but in most studies the assumed hunting range is considered to be a circle with cca. $2 \mathrm{~km}$ radius (Lovari et al. 1976, Martinez \& Zuberogoitia 2004, Torre et al. 2015). On the map of the national scale CORINE Land Cover Project of 2012, 1:50 000 (Feranec et al. 2015), circles with $2 \mathrm{~km}$ radius were marked around the five Barn Owl nesting and roosting places in QGIS program to estimate the distribution of the various landscape types (QGIS 2013). These landscape structures (e.g. Broad-leaved forest, Non-irrigated arable land, Pastures) were classified into 4 habitat types (urban, open, forest and wetland). The comparison of the relative abundances of small mammal functional groups detected in the five samples and the proportion of the habitats within the corresponding hunting ranges were carried out by a homogeneity test $\mathrm{G}$. Canonical correspondence analysis was performed for the relative abundance of small mammal functional groups detected in the five samples, and the proportions of the four habitats in the hunting ranges, which were considered to be environmental variables (Hammer et al. 2001).

\section{Results}

We collected 1,144 Barn Owl pellets in the Marcal Basin from 15 settlements in 2017, in which 3,063 prey items were found. $97.5 \%$ of the prey belonged to 21 small mammal species, while the remaining $2.5 \%$ were birds, frogs and insects (Table la, b). Mammal preys consisted of Cricetidae $40.58 \%$, Muridae $31.15 \%$ and Soricidae $28.09 \%$, and the remnants of European Mole (Talpa europaea) (0.03\%), Kuhl's Pipistrelle (Pipistrellus kuhlii) (0.03\%), Hazel Dormouse (Muscardinus avellanarius) (0.09\%) and Least Weasel (Mustela nivalis) $(0.03 \%)$ were also found in a few samples (Table la, $b)$. 


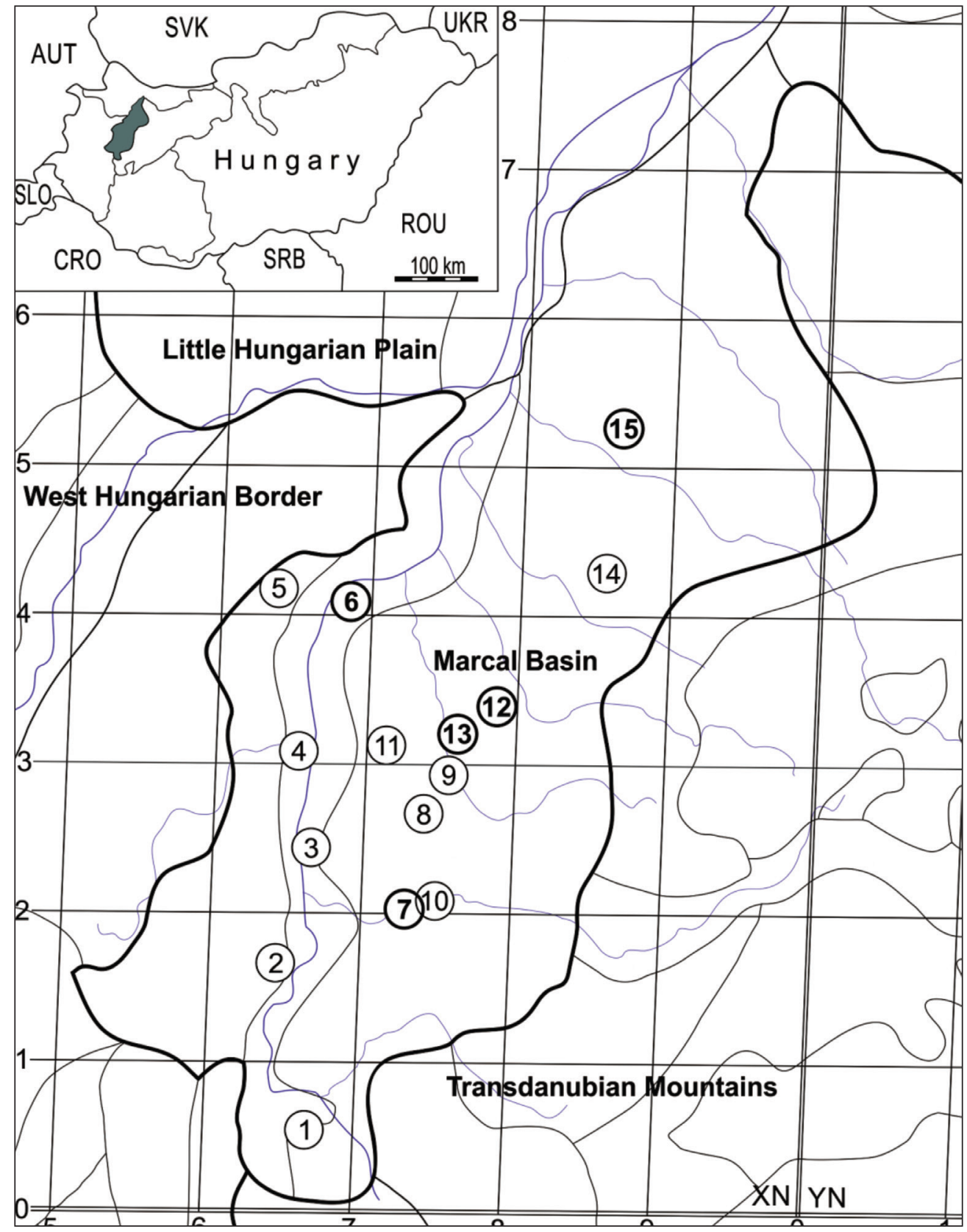

Figure 1. The situation of Marcal Basin in Hungary and sampling locations in the UTM: 1 - Mihályfa, 2 - Nemeskeresztúr, 3 - Nagykamond, 4 - Nemeskocs, 5 - Kemenesszentmárton, 6 Külsővat, 7 - Apácatorna, 8 - Iszkáz, 9 - Kisszőlős, 10 - Tüskevár, 11 - Csögle, 12 - Vid, 13 Nagyalásony, 14 - Kéttornyúlak, 15 - Takácsi (bold circles and numbers - the five sample sites used in the analysis)

1. ábra A 15 mintavételi hely elhelyezkedése a Marcal-medence UTM térképén ábrázolva (félkövér körök számokkal - az öt mintavételi hely, melyek szerepeltek az elemzésekben) 
Table $1 a \quad$ Number of prey specimens in Barn Owl pellets in sampling sites (1-8). Abbreviations: Hp - habitat preference, $\mathrm{u}$ - urban habitat, o - open habitat, $\mathrm{f}$ - forest, $\mathrm{w}$ - wetland, cat - catholic church, ref - reformed church, farm - stables, granaries, UTM - Universal Transverse Mercator coordinate system, the site names of the five largest samples are markt by asterix

$1 a$ táblázat A köpet lelőhelyekről (1-8) előkerült zsákmányállatok egyedszáma. Rövidítések: Hp - habitat (élőhely) preferencia: u - urbán élőhely, o - nyílt élőhely, f- erdő, w - vizes élőhely, cat - katolikus templom, ref - református templom, farm - istálók, magtárak, UTM - Universal Transverse Mercator koordináta rendszer, az öt legnagyobb minta gyűjtési helye csillaggal van jelölve

\begin{tabular}{|c|c|c|c|c|c|c|c|c|c|}
\hline Sampling site number & Hp & 1. & 2. & 3. & 4. & 5. & 6. & 7. & 8. \\
\hline 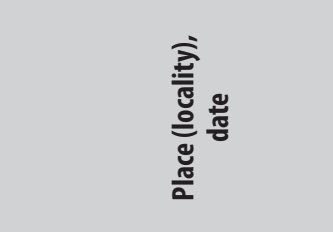 & & 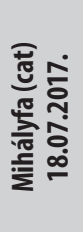 & 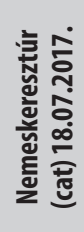 & 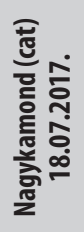 & 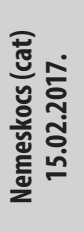 & 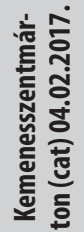 & 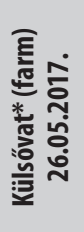 & 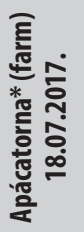 & 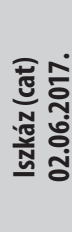 \\
\hline UTM $(10 \times 10 \mathrm{~km})$ & & XN60 & XN61 & XN62 & XN63 & XN64 & $\mathrm{XN64}$ & XN72 & XN72 \\
\hline Crocidura leucodon & o & 0 & 0 & 1 & 2 & 5 & 9 & 6 & 4 \\
\hline Crocidura suaveolens & 0 & 1 & 3 & 1 & 3 & 35 & 12 & 35 & 11 \\
\hline Sorex araneus & $f$ & 23 & 3 & 5 & 5 & 21 & 35 & 27 & 13 \\
\hline Sorex minutus & $f$ & 5 & 0 & 0 & 0 & 1 & 20 & 9 & 2 \\
\hline Neomys anomalus & w & 0 & 0 & 0 & 2 & 3 & 5 & 9 & 1 \\
\hline Neomys fodiens & $w$ & 1 & 0 & 0 & 1 & 0 & 2 & 1 & 0 \\
\hline Talpa europaea & 0 & 0 & 0 & 0 & 0 & 0 & 0 & 0 & 0 \\
\hline Pipistrellus kuhlii & & 0 & 0 & 0 & 0 & 0 & 0 & 0 & 0 \\
\hline Muscardinus avellanarius & $f$ & 0 & 0 & 0 & 0 & 0 & 0 & 0 & 0 \\
\hline Microtus agrestis & $w$ & 2 & 2 & 0 & 0 & 1 & 1 & 1 & 0 \\
\hline Microtus arvalis & 0 & 3 & 35 & 27 & 30 & 47 & 103 & 155 & 106 \\
\hline Microtus subterraneus & o & 0 & 0 & 0 & 3 & 6 & 6 & 4 & 1 \\
\hline Arvicola amphibius & w & 1 & 0 & 2 & 3 & 0 & 13 & 1 & 0 \\
\hline Myodes glareolus & $f$ & 0 & 1 & 1 & 1 & 3 & 5 & 1 & 0 \\
\hline Apodemus agrarius & $f$ & 1 & 4 & 0 & 16 & 38 & 17 & 11 & 11 \\
\hline Apodemus flavicollis & $f$ & 0 & 5 & 2 & 14 & 11 & 5 & 0 & 6 \\
\hline Apodemus sylvaticus & $f$ & 0 & 12 & 2 & 9 & 11 & 28 & 10 & 14 \\
\hline Apodemus sp. & & 0 & 6 & 1 & 4 & 1 & 10 & 5 & 4 \\
\hline Micromys minutus & $w$ & 0 & 0 & 0 & 4 & 15 & 7 & 6 & 1 \\
\hline Mus musculus & $\mathrm{u}$ & 0 & 6 & 0 & 1 & 4 & 1 & 1 & 3 \\
\hline Rattus norvegicus & $\mathrm{u}$ & 0 & 0 & 0 & 0 & 1 & 3 & 1 & 1 \\
\hline Rattus sp. & & 0 & 0 & 0 & 0 & 0 & 0 & 0 & 0 \\
\hline Mustela nivalis & & 0 & 0 & 0 & 0 & 0 & 0 & 0 & 0 \\
\hline Passer sp. & & 0 & 0 & 1 & 0 & 0 & 1 & 0 & 0 \\
\hline Hirundo sp. & & 0 & 0 & 0 & 0 & 0 & 0 & 0 & 0 \\
\hline Turdus sp. & & 0 & 0 & 0 & 0 & 0 & 0 & 0 & 0 \\
\hline Phoenicurus sp. & & 0 & 0 & 0 & 0 & 0 & 0 & 0 & 0 \\
\hline Aves (indet.) & & 0 & 0 & 1 & 1 & 1 & 2 & 1 & 1 \\
\hline Pelobates fuscus & & 0 & 0 & 0 & 0 & 0 & 0 & 0 & 0 \\
\hline Anura (Rana sp.) & & 0 & 0 & 0 & 0 & 0 & 1 & 0 & 1 \\
\hline Anura (indet.) & & 0 & 0 & 0 & 0 & 0 & 2 & 0 & 1 \\
\hline Insecta (Heteroptera) & & 0 & 0 & 0 & 0 & 0 & 0 & 0 & 0 \\
\hline Insecta (Coleoptera) & & 0 & 0 & 1 & 0 & 0 & 1 & 1 & 0 \\
\hline Prey & & 37 & 77 & 45 & 99 & 204 & 289 & 285 & 181 \\
\hline Pellet & & 8 & 48 & 22 & 45 & 62 & 113 & 127 & 68 \\
\hline
\end{tabular}


Table $1 b \quad$ Number of prey specimens in Barn Owl pellets in sampling sites (9-15) $1 b$ táblázat A köpetlelőhelyekről (9-15) előkerült zsákmányállatok egyedszáma

\begin{tabular}{|c|c|c|c|c|c|c|c|c|}
\hline Sampling site number & 9. & 10. & 11. & 12. & 13. & 14. & 15. & $\Sigma$ \\
\hline 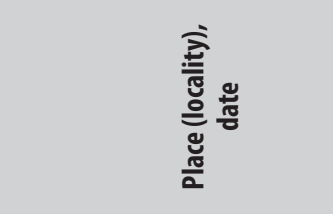 & 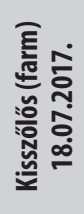 & 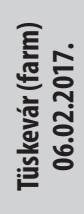 & 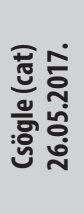 & 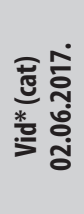 & 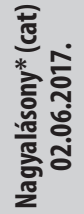 & 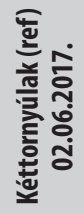 & 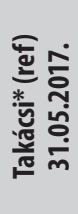 & $\begin{array}{l}\text { त्ञ } \\
\text { 으 }\end{array}$ \\
\hline UTM $(10 \times 10 \mathrm{~km})$ & $\mathrm{XN72}$ & XN72 & XN73 & XN73 & XN73 & XN84 & XN85 & \\
\hline Crocidura leucodon & 1 & 3 & 0 & 12 & 16 & 0 & 9 & 68 \\
\hline Crocidura suaveolens & 8 & 15 & 1 & 78 & 30 & 4 & 12 & 249 \\
\hline Sorex araneus & 15 & 5 & 78 & 29 & 70 & 12 & 106 & 447 \\
\hline Sorex minutus & 0 & 1 & 21 & 23 & 22 & 1 & 21 & 126 \\
\hline Neomys anomalus & 2 & 4 & 9 & 9 & 1 & 0 & 17 & 62 \\
\hline Neomys fodiens & 0 & 0 & 0 & 1 & 3 & 0 & 4 & 13 \\
\hline Talpa europaea & 0 & 0 & 0 & 0 & 1 & 0 & 0 & 1 \\
\hline Pipistrellus kuhlii & 0 & 0 & 0 & 1 & 0 & 0 & 0 & 1 \\
\hline Muscardinus avellanarius & 0 & 0 & 0 & 2 & 0 & 0 & 1 & 3 \\
\hline Microtus agrestis & 0 & 0 & 5 & 0 & 3 & 0 & 0 & 15 \\
\hline Microtus arvalis & 46 & 46 & 37 & 216 & 171 & 55 & 149 & 1226 \\
\hline Microtus subterraneus & 0 & 0 & 1 & 14 & 12 & 4 & 24 & 75 \\
\hline Arvicola amphibius & 1 & 0 & 0 & 3 & 1 & 0 & 1 & 26 \\
\hline Myodes glareolus & 1 & 1 & 4 & 9 & 10 & 0 & 15 & 52 \\
\hline Apodemus agrarius & 2 & 2 & 10 & 60 & 31 & 5 & 54 & 262 \\
\hline Apodemus flavicollis & 4 & 0 & 3 & 17 & 25 & 5 & 11 & 108 \\
\hline Apodemus sylvaticus & 14 & 6 & 9 & 65 & 40 & 52 & 34 & 306 \\
\hline Apodemus sp. & 0 & 0 & 1 & 22 & 8 & 20 & 11 & 93 \\
\hline Micromys minutus & 0 & 1 & 3 & 35 & 19 & 2 & 12 & 105 \\
\hline Mus musculus & 0 & 2 & 2 & 51 & 27 & 6 & 10 & 114 \\
\hline Rattus norvegicus & 0 & 1 & 0 & 47 & 22 & 1 & 5 & 82 \\
\hline Rattus sp. & 0 & 0 & 0 & 4 & 2 & 0 & 0 & 6 \\
\hline Mustela nivalis & 0 & 0 & 0 & 0 & 0 & 0 & 1 & 1 \\
\hline Passer sp. & 0 & 0 & 0 & 0 & 2 & 0 & 5 & 9 \\
\hline Hirundo sp. & 0 & 0 & 0 & 1 & 15 & 0 & 0 & 16 \\
\hline Turdus sp. & 0 & 0 & 1 & 0 & 0 & 0 & 0 & 1 \\
\hline Phoenicurus sp. & 0 & 0 & 0 & 0 & 4 & 0 & 0 & 4 \\
\hline Aves (indet.) & 0 & 0 & 0 & 0 & 1 & 1 & 0 & 9 \\
\hline Pelobates fuscus & 0 & 0 & 0 & 1 & 0 & 0 & 0 & 1 \\
\hline Anura (Rana sp.) & 0 & 0 & 0 & 3 & 4 & 1 & 5 & 15 \\
\hline Anura (indet.) & 0 & 0 & 0 & 0 & 2 & 3 & 2 & 10 \\
\hline Insecta (Heteroptera) & 0 & 0 & 0 & 0 & 0 & 1 & 0 & 1 \\
\hline Insecta (Coleoptera) & 0 & 0 & 0 & 2 & 2 & 1 & 0 & 8 \\
\hline Prey & 94 & 87 & 185 & 705 & 544 & 174 & 57 & 3063 \\
\hline Pellet & 28 & 37 & 37 & 240 & 204 & 72 & 33 & 1144 \\
\hline
\end{tabular}


The proportions of the four functional groups of small mammals detected in the five Barn Owl pellet sampling sites and the proportions of urban, open, forest and wetland habitats within the hunting areas were significantly different in 15 comparisons (75\%) and overlapped only in 5 comparisons $(25 \%$ ) (Table 2). In the samples from Nagyalásony and Takácsi the proportion of species preferring urban habitats showed correlation with the proportion of urban habitats within the assumed hunting areas (Table 2). The proportion of small mammal species preferring open and forest habitats overlapped with the proportion of open and forest habitats within the assumed hunting range in the Apácatorna sample site only (Table 2). The proportion

Table 2. Proportion of small mammals with different habitat preferences (h. pref.) detected from the owl pellet samples collected at the five sampling sites (\%), and the comparison of these values with the share (\%) of habitats (hab.) in the assumed Barn Owl hunting ranges ( $2 \mathrm{~km}$ radius circle)

2. táblázat Az öt mintvételi helyen gyűjtött gyöngybagoly köpetmintából kimutatott kisemlősök részesedése (\%) élőhely-preferenciájuk (h. pref.) alapján, és ezeknek az értékeknek az összevetése a baglyok feltételezett vadászterületén ( 2 km-es sugarú kör) belül kimutatott élőhelyek (hab.) \%-os részesedésével

\begin{tabular}{|c|c|c|c|c|}
\hline Külsővat & h. pref. & hab. & G & $\mathbf{p}$ \\
\hline urban & 1.47 & 8.95 & 5.97 & $<0.05$ \\
\hline open & 47.80 & 91.05 & 13.70 & $<0.001$ \\
\hline forest & 40.44 & 0.00 & 56.06 & $<0.001$ \\
\hline wetland & 10.29 & 0.00 & 14.27 & $<0.001$ \\
\hline Apácatorna & h. pref. & hab. & $\mathbf{G}$ & $\mathbf{p}$ \\
\hline urban & 0.73 & 5.27 & 3.91 & $<0.05$ \\
\hline open & 71.94 & 75.89 & 0.11 & NS. \\
\hline forest & 20.86 & 18.84 & 0.10 & NS. \\
\hline wetland & 6.47 & 0.00 & 8.98 & $<0.01$ \\
\hline Vid & h. pref. & hab. & G & $\mathbf{p}$ \\
\hline urban & 14.61 & 3.08 & 8.16 & $<0.01$ \\
\hline open & 47.69 & 94.27 & 15.24 & $<0.001$ \\
\hline forest & 30.55 & 2.65 & 27.20 & $<0.001$ \\
\hline wetland & 7.15 & 0.00 & 9.73 & $<0.01$ \\
\hline Nagyalásony & h. pref. & hab. & $\mathbf{G}$ & $\mathbf{p}$ \\
\hline urban & 9.72 & 5.88 & 0.96 & NS. \\
\hline open & 45.63 & 82.88 & 10.96 & $<0.01$ \\
\hline forest & 39.29 & 11.24 & 16.18 & $<0.01$ \\
\hline wetland & 5.36 & 0.00 & 7.43 & $<0.01$ \\
\hline Takácsi & h. pref. & hab. & $\mathbf{G}$ & $\mathbf{p}$ \\
\hline urban & 3.09 & 9.44 & 3.37 & NS. \\
\hline open & 40.00 & 80.62 & 13.95 & $<0.01$ \\
\hline forest & 49.90 & 7.84 & 34.15 & $<0.001$ \\
\hline wetland & 7.01 & 2.10 & 2.80 & NS. \\
\hline
\end{tabular}


of species preferring wetland habitats was $5-10 \%$ in every hunting area, and did not overlap with the proportion of wetland habitats within the hunting areas, except for the sample of Takácsi (Table 2).

According to the results of the canonical correspondence analysis, the relative abundance of small mammals preferring urban habitats and the proportion of urban habitats were different, and showed opposite values. We obtained similar results in the cases of open and forest habitats and small mammals preferring those habitats. The proportion of small mammal species preferring wetland habitats was similar to the proportion of the wetland area in the assumed circle of the hunting range. In the corresponding analysis the sample site Apácatorna was very distinguished, since there was a higher proportion of forest in the Barn Owls' hunting

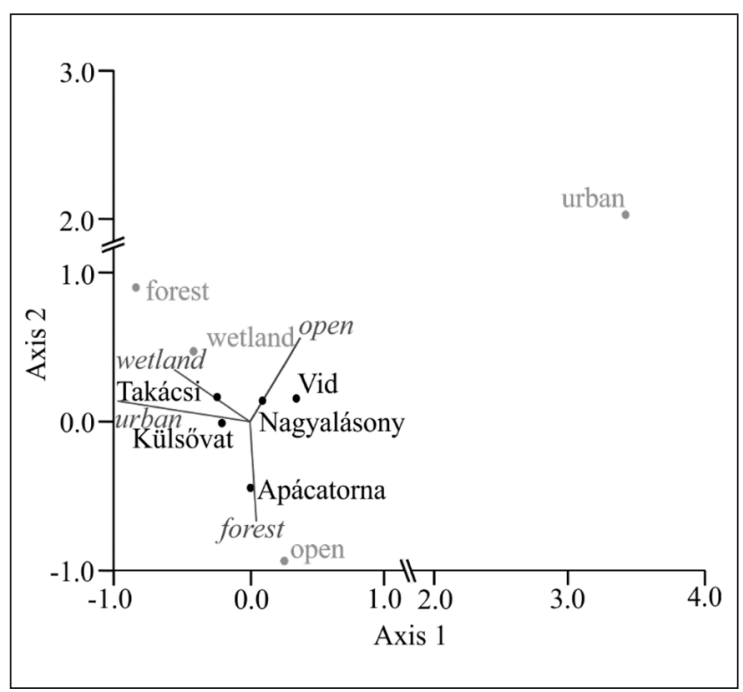

Figure 2. Distribution of sampling sites (names of settlements), habitats (letters in italics) and the habitat preference of small mammal species (normal gray letters) by canonical correspondence analysis

2. ábra A mintavételi helyek (a települések neve), az élőhelyek (dőlt betűk) és az azokat preferáló fajok (normál szürke betűk) eloszlása kanonikus korrespondancia vizsgálat alapján range (Figure 2).

\section{Discussion}

The presence of most of the small mammal species detected in the Marcal Basin was expected, as they are common in the surrounding area (Bihari et al. 2007). Our results contributed to the knowledge of distribution patterns of small mammal species in the study area, since out of our 15 sampling sites similar surveys had been previously carried out only in 3 locations: Mihályfa, Nemeskeresztúr and Nemeskocs (Lázár 1983, Varga 1991, Purger \& Reider 1998). The detection of Kuhl's Pipistrelle from Vid village suggested that individuals of this species occurred farther to the north-east from the already known distribution area (Fehér 2007).

Our results suggested that the representation of small mammal functional groups in the Barn Owl's diet and the proportion of various habitats in the assumed hunting ranges correlated only in $25 \%$ of the comparisons. The presumed hunting range was a circle with a $2 \mathrm{~km}$ radius and since pellet collecting sites were located in the central part of the mostly small rural settlements, thus urban habitats covered only 3-9\%. It was expected that the proportion of urban species in the Barn Owls' diet will be similar, as the owls frequently fly over to urban habitats. Contrary to this expectation, such concordance was shown only in two of the five sample sites, 
while in other two cases the proportion of small mammal species preferring urban habitats was significantly lower, and in one case it was significantly higher than the proportion of urban habitats in the respective hunting range. Brown Rat (Rattus norvegicus) and House Mouse (Mus musculus) were detected in higher numbers in two samples collected from two settlements (Vid, Nagyalásony), which can be explained by the fact that several livestock farms are located there. It is widely known that the role of Brown Rat, House Mouse and House Sparrow in the food source of Barn Owls largely depends on the intensity of livestock farming (Latková 2008). The proportion of these small mammal species was similar in the two samples also because these two settlements are close to each other, thus the hunting ranges of the Barn Owls overlapped substantially.

The proportion of small mammal species preferring open habitats was in concordance with the distribution of open habitats in the Barn Owl hunting range only in one sample, while it was significantly smaller in the other four samples. A possible reason for such discrepancy can be the rough categorisation of habitats in CORINE map, where "Land principally occupied by agriculture, with significant areas of natural vegetation" (e.g. tree lines, reed beds, shrubs) was also classified as open habitat, despite the fact that it can favour other small mammal species with different habitat preferences, too. Barn Owls hunt mainly in open fields (Taylor 1994), and the proportion of species preferring forest or wetland habitats in their prey is higher due to the presence of treelines, shrubs and reed beds, while these small mammal species in the surrounding open areas are more likely to be predated. The proportion of small mammals preferring open habitats was the highest in Apácatorna, although the proportion of open habitats within the assumed hunting range was the smallest there. Apacatorna is one of the settlements affected by red mud disaster in 2010, where the highly alkaline, heavy metal contaminated flood ran through the stream Torna (Uzinger et al. 2015, Mayes et al. 2016). The effects of the disaster cannot be evaluated because of the absence of previous small mammal surveys. We cannot provide satisfactory explanation for our current results, since it is not clear why the highest concordance was revealed between small mammals' preference and the pattern of habitats in owl hunting range only in this site. The highest concordance between species preferring forests and the pattern of forest habitats was revealed in the same sampling site (Apácatorna). In all the other sampling sites, the proportion of species preferring forest habitats in the pellets was much higher than the proportion of forests within the Barn Owl hunting range.

The proportion of species preferring wetland habitats in the pellets showed some concordance with the extent of their habitats within the hunting area in one sample (Takácsi), while in the other sampling sites significantly higher proportions were revealed for such species than the extent of wetland habitats in the corresponding hunting ranges. We assumed that such result is not quite realistic, as there are hidden wetland habitats in the hunting ranges that could not be shown due to the resolution of the used map. Moreover, as mentioned above, the CORINE map shows that many of the wetland habitats are found in the open area habitat category.

Barn Owl pellets had been previously collected in 3 out of our 15 sample sites in the study area. Our current samples were small, therefore the comparison with the results of previous surveys have only informative values. In the sample collected in Mihályfa in 2017, species preferring forest habitat dominated (78\%), similarly to the previous survey in 1977, when their proportion reached 60\% (Lázár 1983). In the sample collected in 2017 from Nemeskeresztúr, 
the proportion of small mammals preferring open and forest habitats was $49 \%$, and $40 \%$, respectively, while in the sample from 1984 this difference was even higher: 69\% of species preferring open habitat versus only 19\% of species preferring forest habitats (Varga 1991). About $50 \%$ of the prey items from Nemeskocs in 2017 were made up of species preferring forest habitats, 39\% were species preferring open habitats, and 10\% were small mammal species typical for wetlands. In the survey conducted in 1996, the species preferring open habitats were highly dominant $(82 \%)$ in the diet of the owls, while the proportion of species preferring forest habitats (17\%) was much lower (Purger \& Reider 1998).

From the comparisons it can be seen that the proportion of functional groups of small mammals preferring different habitats in the diet of Barn Owl may change significantly over time. The causes of these changes are difficult to detect and explain, though it is expected that changes in the landscape structure influence small mammal communities in the owls' hunting ranges. The limitations of the method applied in this study were highlighted by the fact that owl hunting ranges can differ in size and quality (Arlettaz et al. 2010) and their diet composition is influenced by the availability of small mammal species and the finer structure of the landscape (e.g. Bond et al. 2004, Lyman 2012, Horváth et al. 2018). For this reason, we should try to collect samples from the study area for as many years as possible, with seasonal frequency (Fehér \& Fehér 2004). The limitations of the usability of this method are also influenced by the fact that owls hunt not only within the assumed hunting range, and are likely to prefer more accessible species (Moysi et al. 2018). We suggest improving the efficiency of the method by using finer structure of the landscape and more precise definition of habitats. For finding evidence that small mammal prey composition reflects landscape habitat structure the best fitting hunting range size should be established.

\section{Acknowledgements}

We would like to thank the PhD School of Biology and Sport Biology at the University of Pécs for their financial support, and Gábor Vasuta Jr. and the Barn Owl Foundation staff for their help in collecting pellets.

\section{References}

Arlettaz, R., Krähenbühl, M., Almasi, B., Roulin, A. \& Schaub, M. 2010. Wildflower areas within revitalized agricultural matrices boost small mammal populations but not breeding Barn Owls. - Journal of Ornithology 151: 553-564. DOI: 10.1007/s10336-009-0485-0

Askew, N. P., Searle, J. B. \& Moore, N. P. 2007. Prey selection in a Barn Owl Tyto alba. - Bird Study 54: 130132. DOI: $10.1080 / 00063650709461465$

Bihari, Z., Csorba, G. \& Heltai, M. (eds.) 2007. Magyarország emlőseinek atlasza [Atlas of mammals in Hungary]. - Kossuth Kiadó, Budapest (in Hungarian with English Summary)

Bond, G., Burnside, N., G., Metcalfe, D. J., Scott, D. M. \& Blamire, J. 2004. The effects of land-use and landscape structure on Barn Owl (Tyto alba) breeding success in southern England, U.K. - Landscape Ecology 20: 555566. DOI: 10.1007/s10980-004-5037-7

Cooke, D., Nagle, A., Smiddy, P., Fairley, J. \& Muircheartaigh, I. 1996. The diet of the Barn Owl (Tyto alba) in County Cork in relation to land use. - Biology \& Environment: Proceedings of the Royal Irish Academy 96B(2): 97-111. 
de la Peña, N. M, Butet, A., Delettre, Y., Paillat, G., Morant, P., Le Du, L. \& Burel, F. 2003. Response of the small mammal community to changes in western French agricultural landscapes. - Landscape Ecology 18(3): 265278. DOI: $10.1023 / \mathrm{A}: 1024452930326$

Dövényi, Z., Ambrózy, P., Juhász, Á., Marosi, S., Mezősi, G., Michalkó, G., Somogyi, S., Szalai, Z. \& Tiner, T. 2010. Magyarország kistájainak katasztere [Inventory of microregions in Hungary]. - HAS Geographical Research Institute, Budapest (in Hungarian)

Fehér, Cs. E. 2007. Fehérszélü törpedenevér Pipistrellus kuhlii (Kuhl, 1819) [Nathusius' Bat Pipistrellus kuhlii (Kuhl, 1819)]. - In: Bihari, Z., Csorba, G. \& Heltai, M. (eds.) Magyarország emlöseinek atlasza [Atlas of mammals in Hungary]. - Kossuth Kiadó, Budapest, pp. 83-84. (in Hungarian with English Summary)

Fehér, E. \& Fehér, Cs. E. 2004. A gyöngybagoly (Tyto alba) táplálékösszetételének éven belüli változása [Seasonal changes in the diet of Barn Owl (Tyto alba)]. - Aquila 111: 81-87. (in Hungarian with English Summary)

Feranec, J., Soukup, T., Čižmár, J., Šafár, J. \& Kontra, P. 2015. CORINE land cover map of Europe. - Cartographic Letters 23: 21-28.

Hammer, Ø., Harper, D. A. T. \& Ryan, P. D. 2001. PAST: Paleontological statistics software package for education and data analysis. - Paleontologia Electronica 4: 1-9.

Heisler, L. M., Somers, C. M. \& Poulin, R. G. 2016. Owl pellets: a more effective alternative to conventional trapping for broad-scale studies of small mammal communities. - Methods in Ecology and Evolution 7(1): 96103. DOI: $10.1111 / 2041-210 X .12454$

Horváth, A., Morvai, A. \& Horváth, G. F. 2018. Food-niche pattern of the Barn Owl (Tyto alba) in intensively cultivated agricultural landscape. - Ornis Hungarica 26(1): 27-40. DOI: 10.1515/ orhu-2018-0002

Kessler, J. 2015. Osteological guide of songbirds from Central Europe. - Ornis Hungarica 23(2): 62-155. DOI: 10.1515/orhu-2015-0016

Kryštufek, B. \& Janžekovič, F. (eds.) 1999. Ključ za določanje vretenčarjev Slovenije [Key for identification of vertebrates in Slovenia]. - DZS, Lubljana (in Slovenian)

Latková, H. 2008. Seasonal changes in food composition of the Barn Owl (Tyto alba) in the northern part of the “Záhorie" region. - Slovak Raptor Journal 2: 107-112. DOI: 10.2478/v10262-012-0024-4

Lázár, P. 1983. Adatok Sümeg környéke apróemlősfaunájához bagoly-köpetvizsgálatok alapján [Data on small mammals fauna based on owl pellets analysis in the Sümeg surroundings]. - Folia Musei Historico-Naturalis Bakonyiensis 2: 217-228. (in Hungarian with German Summary)

Lovari, S., Renzoni, A. \& Fondi, R. 1976. The predatory habits of the Barn Owl (Tyto alba Scopoli) in relation to the vegetation cover. - Bolletino di Zoologia 43(1-2): 173-191. DOI: 10.1080/11250007609434894

Lyman, R. L. 2012. Rodent-prey content in long-term samples of Barn Owl (Tyto alba) pellets from the northwestern United States reflects local agricultural change. - The American Midland Naturalist 167(1): 150-163. DOI: $10.1674 / 0003-0031-167.1 .150$

Martinez, J. A. \& Zuberogoitia, I. 2004. Habitat preferences and causes of population decline for Barn Owls Tyto alba: a multi-scale approach. - Ardeola 51(2): 303-317.

März, R. 2011. Gewöll- und Rupfungskunde [The science of pellets and pluck]. - Aula-Verlag, Wiebelsheim (in German)

Mayes, W. M., Burke, I. T., Gomes, H. I., Anton, Á. D., Molnár, M., Feigl, V. \& Ujacki, É. 2016. Advances in understanding environmental risks of red mud after the Ajka Spill, Hungary. - Journal of Sustainable Metallurgy 2: 332-343. DOI: 10.1007/s40831-016-0050-z

Meek, W. R., Burman, P. J., Sparks, R. H., Nowakowski, M. \& Burman, N. J. 2012. The use of Barn Owl Tyto alba pellets to assess population change in small mammals. - Bird Study 59(2): 166-174. DOI: 10.1080/00063657.2012.656076

Mesterházy, A. 2008. Marcal-medence [Marcal Basin]. - In: Király, G., Molnár, Zs., Bölöni, J., Csiky, J. \& Vojtkó, A. (eds.) 2008. Magyarország földrajzi kistájainak növényzete [Vegetation of geographical microregions in Hungary]. - MTA ÖBKI, Vácrátót, pp. 85-87. (in Hungarian)

Mikkola, H. 1983. Owls of Europe. - T \& AD Poyser, Calton

Moysi, M., Christou, M., Goutner, V., Kassinis, N. \& Iezekiel, S. 2018. Spatial and temporal patterns in the diet of Barn Owl (Tyto alba) in Cyprus. - Journal of Biological Research - Thessaloniki 25: 9. DOI: 10.1186/ s40709-018-0080-8

Paunović, M. 1990. Vodozemci iz prošlosti i sadašnjosti: određivanje skeletnih dijelova [Amphibians from past and present: determination of skeletal parts]. - Mala znanstvena knjižnica, Hrvatsko Prirodoslovno Društvo, Zagreb (in Croatian) 
Purger, J. J. \& Reider, M. 1998. Celldömölk környékének kisemlösfaunája, gyöngybagoly-köpetek vizsgálata alapján [Small mammal fauna of the Celldömölk surroundings obtained by Barn Owl pellet analysis]. - Természetvédelmi Közlemények 7: 135-140. (in Hungarian with English Summary)

QGIS (Quantum GIS Development Team) 2013. Quantum GIS Geographic Information System. - Open Source Geospatial Foundation Project. Version 2.12 - retrieved from http://www.qgis.org/.

Rodríguez, C. \& Peris, S. J. 2007. Habitat associations of small mammals in farmed landscapes: implications for agri-environmental schemes. - Animal Biology 57(3): 301-314. DOI: 10.1163/157075607781753092

Schmidt, E. 1967. Bagolyköpetvizsgálatok [Owl pellet analyses]. - Magyar Madártani Intézet, Budapest (in Hungarian)

Schmidt, E. 1976. Kleinsäugerfaunistische Daten aus Eulengewöllen in Ungarn [Small mammal data from Barn Owl pellets in Hungary]. - Aquila 82: 119-144. (in German)

Schmidt, E. 1979. Adatok Vas megye kisemlős faunájához baglyok táplálékvizsgálata alapján [Data to the knowledge of small mammal fauna of Vas County based on the diet analysis of owls]. - Savaria, A Vas Megyei Múzeumok Értesítője 7-8: 71-77.

Szép, D. \& Purger, J. J. 2013. Óhid és Kisgörbő környékének (Zala megye) kisemlős faunája gyöngybagoly (Tyto alba) köpetek vizsgálata alapján [Small mammal fauna of the surroundings of Óhíd and Kisgörbő (Zala County, Hungary), based on Barn Owl (Tyto alba) pellet analysis]. - Folia Musei Historico-Naturalis Bakonyiensis 30: 147-152. (in Hungarian with English Summary)

Taylor, I. 1994. Barn Owls: Predator-Prey Relationships and Conservation. - Cambridge University Press, Cambridge, UK.

Tores, M., Motro, Y., Motro, U. \& Yom-Tov, Y. 2005. The Barn Owl - a selective opportunist predator. - Israel Journal of Zoology 51(4): 349-360. DOI: 10.1560/7862-9E5G-RQJJ-15BE

Torre, I., Arrizabalaga, A. \& Flaquer, C. 2004. Three methods for assessing richness and composition of small mammal communities. - Journal of Mammalogy 85(3): 524-530. DOI: 10.1644/BJK-112

Torre, I., Gracia-Quintas, L., Arrizabalaga, A., Baucells, J. \& Mario, D. 2015. Are recent changes in the terrestrial small mammal communities related to land use change? A test using pellet analyses. - Ecological Research 30(5): 813-819. DOI: 10.1007/s11284-015-1279-x

Tvrtković, N. 1979. Razlikovanje i određivanje morfološki sličnih vrsta podroda Sylvaemus Ognev \& Vorobiev 1923. (Rodentia, Mammalia) [Distinguishing and determination of the morphologically similar species of subgenus Sylvaemus Ognev et Vorobiev 1923 (Rodentia, Mammalia)]. - Rad JAZU 383: 155-186. (in Croatian with German Summary)

Tvrtković, N., Đulić, B. \& Mrakovčić, M. 1980. Distribution, species characters, and variability of the Southern Water-shrew, Neomys anomalus Cabrera, 1907 (Insectivora, Mammalia) in Croatia. - Biosistematika 6(2): 187-201.

Ujhelyi, P. 1989. A magyarországi vadonélő emlősállatok határozója (küllemi és csonttani bélyegek alapján) [Key for identification of wild mammals of Hungary (on the base of habitus and features of sceleton)]. - A Magyar Madártani és Természetvédelmi Egyesület (MME) Könyvtára 1. Budapest (in Hungarian)

Uzinger, N., Anton, Á. D., Ötvös, K., Tamás, P. \& Anton, A. 2015. Results of the clean-up operation to reduce pollution on flooded agricultural fields after the red mud spill in Hungary. - Environmental Science and Pollution Research 22: 1-9.

Varga, L. 1986. Adatok a gyöngybagoly táplálkozásához [Data to the knowledge of diet of Barn Owl]. - Vasi Madártani Értesítő 1: 8.

Varga, L. 1991. Adatok néhány gerinces (Vertebrata) állatfaj Vas megyei elterjedéséhez [Data to the distribution of several vertebrate (Vertebrata) species in Vas County]. - Vasi Szemle 45(1): 7-14.

Yom-Tov, Y. \& Wool, D. 1997. Do the contents of Barn Owl pellets accurately represent the proportion of prey species in the field? - The Condor 99(4): 972-976. DOI: 10.2307/1370149 